\title{
Anaerobic co-digestion of swine manure with sweet potato or cassava in different $\mathrm{C} / \mathrm{N}$ ratios
}

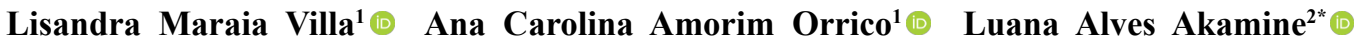 Jorge de Lucas Junior ${ }^{3}$ (i) Natália da Silva Sunada ${ }^{4}$ ()}

${ }^{1}$ Universidade Federal da Grande Dourados (UFGD), Dourados, MS, Brasil.

${ }^{2}$ Faculdade de Ciências Agrárias (FCA), Universidade Estadual Paulista (Unesp), 18610-034, Botucatu, SP, Brasil. E-mail: luana.a.akamine@gmail.com. ${ }^{*}$ Corresponding author.

${ }^{3}$ Departamento de Engenharia Rural, Faculdade de Ciências Agrárias e Veterinárias (FCAV), Universidade Estadual Paulista (Unesp), Jaboticabal, SP, Brasil.

${ }^{4}$ Centro Universitário da Grande Dourados (UNIGRAN), Dourados, MS, Brasil.

ABSTRACT: Anaerobic co-digestion (AcoD) of waste is a method of increasing methane (CH) yield and improving biofertilizer quality. This study aimed to evaluate the best AcoD conditions for swine manure (SM) with sweet potato (SP) or cassava (C) in different amounts in semicontinuous biodigesters. Initially, using batch biodigesters, an AcoD test of the SM with SP or C was performed, adopting carbon/nitrogen $(C / N)$ ratios of 10/1, 13/1, 17/1, and 22/1. Based on the results, a C/N ratio of 10/1 was chosen, which was the proportion that resulted in the highest reduction of volatile solids (VS) and specific biogas production. From these results, the experiment was carried out in semi-continuous biodigesters, consisting of three treatments (control (SM), SP 10/1, and C 10/1) with five replicates and a hydraulic retention time (HRT) of 30 days. Total solid (TS) and volatile solid (VS) reductions, biogas and $\mathrm{CH}_{4}$ yields, alkalinity, and volatile acidity were measured. The control treatment differed from the others and resulted in decreased biogas yield (752 $\left.\mathrm{L}_{N} . \mathrm{kg}_{V \mathrm{~S}^{-1}}{ }^{-1}\right), \mathrm{CH}_{4}\left(449 \mathrm{~L}_{N} \cdot \mathrm{kg}_{V S}{ }^{-1}\right)$, and $\mathrm{CH}_{4} \mathrm{content}(59.7 \%)$. The AcoD treatments (SP and C) did not differ significantly for biogas yield (respectively, 901 and $883 \mathrm{~L}_{N} . \mathrm{kg}_{V \text { Sadded }}{ }^{-1}$ ) and $\mathrm{CH}_{4}($ respectively, 590 and $547 \mathrm{~L}_{N} \mathrm{~kg}_{V \text { sadded }}^{-1}$ ); however, they differed in $\mathrm{CH}_{4}$ content (65.5\% and $61.9 \%$ respectively). The treatments showed general reduction averages of $76.1 \%$ and $85.9 \%$ for TS and VS, respectively, with no statistical difference found between them. The AcoD of the SM with SP or C increased the production and quality of the biogas, increasing the concentration of $\mathrm{CH}_{4}$ therein.

Key words: acidification, anaerobic biodigestion, carbohydrates, methanogenesis, tuberous roots.

Co-digestão anaeróbia dos dejetos de suínos com batata doce ou mandioca em diferentes relações $\mathrm{C} / \mathrm{N}$

RESUMO: A co-digestão anaeróbia dos resíduos é uma alternativa para aumentar a produção de metano (CH) e melhorar a qualidade do biofertilizante. Este estudo teve como objetivo avaliar a melhor condição de coDA dos dejetos de suínos (DS), acrescidos de batata doce (BD) ou mandioca $(M)$ em diferentes inclusões, em biodigestores semi-contínuos. Inicialmente, utilizando biodigestores batelada, foi realizado ensaio de coDA dos DS com BD ou $M$, adotando-se as relações $C / N$ iguais a 10/1, 13/1, 17/1, e 22/1. Com base nos resultados elegeu-se a relação $C / N$ de 10/1, como sendo a proporção que apresentou maiores reduções de sólidos voláteis (SV) e produções específicas de biogás. A partir destes resultados, efetivou-se o experimento em biodigestores semi-contínuos, composto por três tratamentos (controle (DS), BD 10/1 e M 10/1) com cinco repetições cada, e tempo de retenção hidráulica (TRH) de 30 dias. Foram mensuradas as reduções de sólidos totais (ST) e sólidos voláteis $(S V)$, produções de biogás e $\mathrm{CH}_{4}$, alcalinidade e acidez volátil. O tratamento controle diferiu dos demais e apresentou menor desempenho no rendimento de biogás (752 $\left.\mathrm{L}_{N} \cdot \mathrm{kg}_{\text {SVadic }}{ }^{-1}\right), \mathrm{CH}_{4}\left(449 \mathrm{~L}_{\mathrm{N}} \mathrm{kg}_{\text {SVadic }}{ }^{-1}\right.$ ) e concentração de $\mathrm{CH}_{4}(59,7 \%)$. Os tratamentos em coDA (BD e M) não diferiram entre si para o rendimento de biogás (901 e $\left.883 \mathrm{~L}_{N} \mathrm{~kg}_{\text {SVadic }}{ }^{-1}\right)$ e $\mathrm{CH}_{4}\left(590\right.$ e $\left.547 \mathrm{~L}_{N^{*}} \mathrm{~kg}_{\text {SVadic }^{-1}}\right)$, no entanto diferiram na concentração de $\mathrm{CH}_{4}(65,5$ e 61,9\%, respectivamente). Os tratamentos apresentaram médias gerais de reduções de 76,1 e 85,9\% para ST e SV, respectivamente, não sendo encontrada diferença estatística entre eles. A coDA do DS com BD ou M aumentou a produção e a qualidade do biogás, elevando a concentração de $\mathrm{CH}_{4}$ no mesmo.

Palavras-chave: acidificação, biodigestão anaeróbia, carboidratos, metanogênese, raízes tuberosas.

\section{INTRODUCTION}

Pig farming, as an activity with high polluting power, has animal waste one of the most studied substrates in anaerobic digestion (AD). Such waste has a high conversion capacity to biogas and methane $\left(\mathrm{CH}_{4}\right)$, which can be used individually or as co-substrates in association with other wastes.

Anaerobic co-digestion (AcoD), which consists of the association of two or more residues, 
enables the adjustment of the ratio between carbon and nitrogen $(\mathrm{C} / \mathrm{N})$, the reduction of possible toxic compounds, and the balancing of the environmental $\mathrm{pH}$, in addition to promoting adequate availability of macro and micro nutrients (SIDDIQUE \& WAHID, 2018). Thus, the addition of plant materials to the medium in the digestion of animal waste is indicated because it provides a balance in the $\mathrm{C} / \mathrm{N}$ ratio and consequently increases the efficiency of the AD process (HASSAN et al., 2017). These materials allowed an additional carbon supply compared to $\mathrm{SM}$, which has a $\mathrm{C} / \mathrm{N}$ ratio ranging from 6 to 8 (LORIMOR et al., 2000). In addition, the SM has a high buffering capacity, biodegradability, and ammonia concentration, factors that optimize the degradation process (MOLINUEVO-SALCES et al., 2012; MATA-ALVAREZ et al., 2014).

Energy crops such as sweet potatoes (SP; Ipomoea batatas (L.) Lam.) and cassava (C; Manihot esculenta Crantz) have the potential for bioenergy generation (THUMÉ et al., 2013; OKUDOH et al., 2014; MONTORO et al., 2019) due to the high availability of carbon, being starch its main carbohydrate (25-31\% of dry matter) (TABORDA et al., 2015). These organic materials are considered the primary source of energy for microorganisms due to their rapid degradability; and they therefore, can be easily metabolized and hydrolyzed (LE \& STUCKEY, 2017). Thus, when these materials are mixed with swine manure (SM) in appropriate proportions, it is possible to obtain better stability for the AD process, higher biogas production and $\mathrm{CH}_{4}$ yield, as observed by PANICHNUMSIN et al. (2010) and DAMACENO et al. (2019).

The high concentration of easily degradable carbohydrates leads to the high formation of volatile fatty acids (VFAs) in hydrolysis and the consequent failure of the AD process (DORNACK, 2012). In this way, the ideal $\mathrm{C} / \mathrm{N}$ ratio to be applied in the process is influenced by the composition of the materials used in AcoD as well as the availability and degradability of the carbon fraction of these co-products.

The AcoD of SM and cassava pulp (the residue from cassava processing) was evaluated by PANICHNUMSIN et al. (2010) and REN et al. (2014), and they obtained a higher $\mathrm{CH}_{4}$ yield and higher reduction of total solids (TS) and volatile solids (VS) when using the pulp in association with SM. The best results in both studies were obtained in proportions of 60:40 (pulp:SM), with $\mathrm{C} / \mathrm{N}$ ratios of $33 / 1$ and $95.6 / 1$, resulting in increases of $25 \%$ and $41 \%$ in the specific $\mathrm{CH}_{4}$ production, respectively. In the AcoD of cattle manure (CM) and potato pulp,
SANAEI-MOGHADAM et al. (2014) reported higher efficiency for a proportion of 20:80 (pulp:CM; $\mathrm{C} / \mathrm{N} 15.5 / 1$ ), which exhibited an increase of $137 \%$ in the specific production of $\mathrm{CH}_{4}$ compared to the value of $147 \mathrm{~L}_{\mathrm{N}} \cdot \mathrm{kg}_{\mathrm{VSadded}}{ }^{-1}$ reported in the monodigestion of cattle manure (C/N 11.7/1).

Most substrates used in AcoD are agroindustrial by-products, which can result in lower potential for biogas production with lower methane proportions if compared to in natura tuberous roots. Due to the high energy concentration of the in natura tuberous roots, they will be included in small proportions in the substrate when used in AcoD, as, in most cases, they are a surplus product or waste condition with lower commercial value in the market. Therefore, this study aimed to find the most appropriate $\mathrm{C} / \mathrm{N}$ ratio that allows for an increase in biogas and $\mathrm{CH}_{4}$ production and the reduction of TS and VS in the AcoD of SM with SP or C, in natura, in semi-continuous biodigesters.

\section{MATERIAL AND METHODS}

This research was conducted in the Laboratory of Biomass I and Anaerobic Biodigestion of the Rural Engineering Department, using the waste generated in the Swine Farming Sector, both belonging to the Faculty of Agricultural and Veterinary Sciences of the São Paulo State University "Júlio de Mesquita Filho"/UNESP-Jaboticabal Campus $\left(21^{\circ} 14^{\prime} 05^{\prime}\right.$ " S; $\left.48^{\circ} 17^{\prime} 09^{\prime \prime} \mathrm{W}\right)$ at an average altitude of $613.68 \mathrm{~m}$.

The study was carried out in two stages with the digesters kept in a covered shed, sheltered from sun and rain, thus allowing greater control of the thermal variation. In the first stage, batch digesters were used, where the substrates are added to the fermentation chamber only once, thereby evaluating the potential for degradation of organic constituents and consequent biogas production. In the second stage, the most favorable SP or $\mathrm{C}$ inclusions were selected, evaluating the efficiency and stability of the process in semi-continuous biodigesters.

The collection of the SM was done by scraping the floor without adding water. The swine were fed with corn and soybean meal diets that were formulated to meet the requirements of the termination phase. The SP and C were purchased, weekly, in local retail stores, keeping all materials stored under refrigeration at $6{ }^{\circ} \mathrm{C}$ until use. The inoculum came from a semi-continuous biodigester supplied with cattle manure, with stabilized biogas production and methane content equal to $60 \%$ or more in its composition. The SM, SP, and C that were used had the 
following compositions: $29.3 \%, 27.2 \%$, and $38.3 \%$ of TS ( $\%$ of natural matter) and $80.3 \%, 96.1 \%$, and $95.7 \%$ of VS ( $\%$ of TS); $29.6 \%, 38.1 \%$, and $38.8 \%$ of carbon ( $\%$ of TS); and $3.62 \%, 0.79 \%$, and $0.53 \%$ of nitrogen ( $\%$ of TS), respectively.

The batch biodigesters used have been described by SCHWINGEL et al. (2019). In this stage, the goal was to evaluate the different $\mathrm{C} / \mathrm{N}$ ratios $(10 / 1,13 / 1,17 / 1$, and 22/1) for substrates prepared with SM and SP or C additions. A completely randomized design (CRD) was adopted, with nine treatments and four repetitions: control $(100 \%$ swine manure), SP 10/1, SP $13 / 1$, SP $17 / 1$, SP $22 / 1$, C $10 / 1$, C 13/1, C 17/1, and C 22/1, totaling 36 batch biodigesters with 90 -day HRTs. The purpose of this first step was to verify which $\mathrm{C} / \mathrm{N}$ ratios presented the highest energy potentials (biogas yields) and TS and VS reductions. To supply the batch digesters, inoculum preparation $(0.45 \% \mathrm{TS})$ was performed, which was added in the amount of $15 \%$ of the total volume of the substrate $(1.8 \mathrm{~L})$ as a mechanism to accelerate the process. The concentration of TS to supply each biodigester was equal to $4 \%$, varying the proportion of SM, SP, or $\mathrm{C}$ added to adjust the $\mathrm{C} / \mathrm{N}$ ratio in each treatment.

In the second stage, with the data collected in the first, semi-continuous biodigesters described by MONTORO et al. (2019) were used. The experimental treatments were distributed in the CRD, consisting of three substrates (control (SM), SP 10/1, and $\mathrm{C} 10 / 1$ ) and five repetitions, totaling 15 digesters. The HRT used was 30 days; therefore, as the useful volume of the reactors was $60 \mathrm{~L}$, the daily feeds/loads were $2 \mathrm{~L}$. In this second stage, the proportions used in the mixtures were calculated based on a TS amount of $2 \%$. The mixture of substrate composition was homogenized in an industrial blender, reducing the average particle size to $2 \mathrm{~mm}$, and transferred to the biodigesters. Initially, the digesters were filled with inoculum, and daily loads were conducted for 12 successive days with SM as the substrates with $2 \%$ TS concentrations. After this period, the inclusion of SP and $\mathrm{C}$ was initiated for another 50 days, after which the stabilization of biogas production was achieved; another 47 days of follow-up then proceeded. In the supply (affluent) and destocking (effluent) steps, analyses of TS, VS, pH, alkalinity, and volatile acidity were performed.

\section{Applied Methodologies}

The quantities of each substrate to be added in the treatments were calculated on the basis of equation 1 proposed by TRAUTMANN \& KRASNY (1997):

$$
\mathrm{W}_{2}=\frac{\left(\mathrm{W}_{1} \cdot \mathrm{N}_{1}\right) \cdot\left(\mathrm{R}-\left(\frac{\mathrm{C}_{1}}{\mathrm{~N}_{1}}\right)\right) \cdot\left(100-\mathrm{M}_{1}\right)}{\mathrm{N}_{2} \cdot\left(\left(\frac{\mathrm{C}_{2}}{\mathrm{~N}_{2}}\right)-\mathrm{R}\right) \cdot\left(100-\mathrm{M}_{2}\right)} \quad \text { Equation (1) }
$$

in which $\mathrm{W}_{2}$ is the mass $(\mathrm{kg})$ of the tuberous root to be used to balance a desired mass of manure in terms of the $\mathrm{C} / \mathrm{N}$ ratio; $\mathrm{W}_{1}$ is the total known mass of the SM used in the AcoD; $\mathrm{N}_{1}$ is the nitrogen content (\%) of the $\mathrm{SM}$; $\mathrm{R}$ is the $\mathrm{C} / \mathrm{N}$ ratio needed for $\mathrm{AcoD} ; \mathrm{C}_{1}$ is the $\mathrm{C}$ content $(\%)$ of $\mathrm{SM} ; \mathrm{M}_{1}$ is the moisture (\%) of $\mathrm{SM}$ in AcoD; $\mathrm{N}_{2}$ is the nitrogen content (\%) of the tuberous root; $\mathrm{C}_{2}$ is the carbon content (\%) of the tuberous root; and $\mathrm{M}_{2}$ is the moisture (\%) of the tuberous root.

The volume of biogas produced daily was determined by measuring the vertical displacement of the gasometers and multiplying the recorded data by the area of their internal cross-section $\left(0.00785 \mathrm{~m}^{2}\right.$ for the batch digesters and $0.04909 \mathrm{~m}^{2}$ for the biodigester with a semi-continuous feed). Throughout the process, the temperature, biogas volumes, and environmental measurements were recorded. The volume of biogas produced was corrected to $1 \mathrm{~atm}$ and $0{ }^{\circ} \mathrm{C}$ conditions using a combination of the Boyle and Gay-Lussac laws, recorded in liters $\left(\mathrm{L}_{\mathrm{N}}\right)$. The composition of the biogas $\left(\mathrm{CH}_{4}\right.$ and $\left.\mathrm{CO}_{2}\right)$ was analyzed weekly in a Tracera chromatograph, CG-2010 Plus model, according to the methodology described by MONTORO et al. (2019).

Analyses were performed for the characterization of the waste used as substrates, quantifying the TS, VS, and mineral matter (MM) levels according to APHA (2005); $\mathrm{C}$ and $\mathrm{N}$ were quantified using the elementary analyzer LECO model TruSpec CN628 (LECO INSTRUMENTS, ST JOSEPH, MICHIGAN, USA). During the AD test, the $\mathrm{pH}$, total alkalinity (APHA, 2005), and volatile acidity by titrimetry (DILALLO \& ALBERTSON, 1961) were also measured.

The specific biogas and $\mathrm{CH}_{4}$ productions were calculated considering the total production values divided by the amounts of TS and VS added in the biodigesters $\left(\mathrm{L}_{\mathrm{N}}\right.$. $\mathrm{kg}_{\text {TSadded }}{ }^{-1}$ and $\mathrm{L}_{\mathrm{N}} \cdot \mathrm{kg}_{\mathrm{VSadded}}{ }^{-1}$, respectively). Figure 1 shows the specific productions of biogas and $\mathrm{CH}_{4}$ by $\mathrm{VS}_{\text {added }}$ during the time the productions were monitored.

The results were evaluated via analysis of variance (ANOVA) and comparison of means by the Tukey Test at a 5\% probability level, using the SISVAR 5.6 computer program for statistical analysis (FERREIRA, 2014).

\section{RESULTS AND DISCUSSION}

\section{Batch Digesters}

The AcoD of SM with SP, for all the C/N ratios evaluated, presented an average TS reduction 


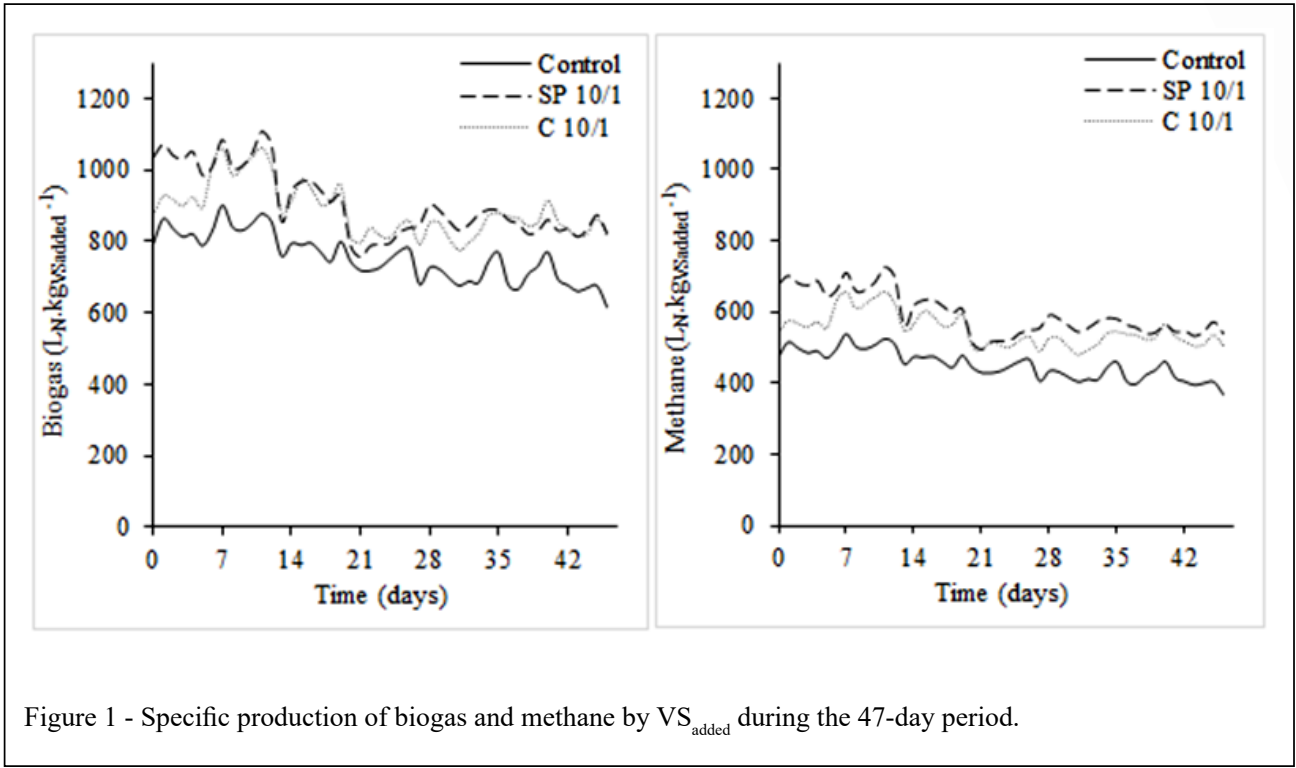

of $45.1 \%$, with no difference for this parameter (Table 1). For the inclusion of $\mathrm{C}$ in the substrates, the largest reductions of TS and VS (45\% and 56\%) occurred in the $10 / 1 \mathrm{C} / \mathrm{N}$ ratio, which did not differ from the distinct $\mathrm{C} / \mathrm{N}$ ratios for the $\mathrm{SP}$ and the control. The solids reduction values did not follow the average biogas production values, and this can be explained by the sedimentation of solids and difficulty in sampling, mainly for the SP 22/1, SP 13/1, C 17/1, and $\mathrm{C} 22 / 1$ treatments.

DAMACENO et al. (2019) also reported no significant difference for the reduction of solids between the monodigestion of poultry sludge and a sludge:SP ratio of $80: 20(\mathrm{C} / \mathrm{N}$ ratios of 6.0 and 7.6 , respectively) in model batch biodigesters ( $4.5 \%$ of TS) with an HRT of 145 days, leaving these treatments with mean reductions of $48.2 \%$ for TS and $57.6 \%$ for VS. The mean reduction of sugars for AcoD was $88.4 \%$, with a $90 \%$ reduction for the 80:20 ratio, which was verified as a harmonic combination of the substrates because it led to a higher production of biogas. A similar observation can be made in the present study for the SP 10/1 treatment, which reached the highest total biogas production $\left(17.9 \mathrm{~L}_{\mathrm{N}}\right)$. The beneficial effect of the harmonic combination of substrates may be due to the rapid hydrolysis of the sugars that were present, which is associated with a high conversion rate to biogas, suggesting that anaerobic organisms were using the food source effectively in the presence of a high buffer capacity and sufficient micronutrients (LE \& STUCKEY, 2017).
For the 40:60 and 20:80 ratios (C/N ratios of 9.2 and 12.2, respectively), DAMACENO et al. (2019) reported $\mathrm{pH}$ values $\leq 5.2$, coinciding with the lowest solids reduction and biogas production values, as we also observed in the present study for SP 22/1, C 13/1, C 17/1, and C 22/1 treatments. These pH values suggested process instability, indicating rapid and excessive accumulation of VFAs formed in the hydrolysis of sugars that were present, making the environment inhibitory for methanogenic bacteria (BROWN \& LI, 2013), which resulted in a significant reduction in biogas production. This behavior is possibly associated with the ability to degrade solids in digestion, which are added to the medium with the inclusion of SP or C but that also come from pig manure; although digestible, the extent of its degradation may be limited depending on the conditions of the medium, which can be easily acidified with the accumulation of acids. Therefore, it is understood that, with the increased participation of SP or C in the substrates, the proportion of easily digestible carbohydrates increased, which could result in higher degradations of TS and VS; however, due to the rapid initial degradation of the easily digestible constituents, VFA accumulation may have occurred in the medium, hindering the sequence of degradation.

It is also possible that, with the degradation of the two cyanogenic glycosides (linamarin and lotaustraulin) contained in cassava (LINHARES et al., 2018), hydrocyanic acid was formed, which may have more drastically influenced the drop in $\mathrm{pH}$ (Table 1), 
Table 1 - Characteristics of affluent and effluent and specific biogas production values in batch biodigesters in anaerobic co-digestion of swine manure (SM), sweet potato (SP), and cassava (C) with different $\mathrm{C} / \mathrm{N}$ ratios.

\begin{tabular}{|c|c|c|c|c|c|c|c|c|c|c|}
\hline \multirow[t]{2}{*}{ Parameters } & \multicolumn{9}{|c|}{--------1 } & \multirow[t]{2}{*}{ CV (\%) } \\
\hline & Control & SP $10 / 1$ & SP $13 / 1$ & SP $17 / 1$ & SP $22 / 1$ & C $10 / 1$ & $\mathrm{C} 13 / 1$ & $\mathrm{C} 17 / 1$ & $\mathrm{C} 22 / 1$ & \\
\hline $\mathrm{pH}$ (afflu.) & 6.9 & 7.0 & 7.1 & 7.3 & 7.4 & 7.0 & 7.1 & 7.2 & 7.3 & 0.57 \\
\hline pH (efflu.) & $7.4^{\mathrm{a}}$ & $7.3^{\mathrm{a}}$ & $7.3^{\mathrm{a}}$ & $7.3^{\mathrm{a}}$ & $5.3^{\mathrm{b}}$ & $7.3^{\mathrm{a}}$ & $5.6^{\mathrm{b}}$ & $4.9^{\mathrm{c}}$ & $4.5^{\mathrm{c}}$ & 2.5 \\
\hline $\mathrm{TS}\left(\mathrm{g} \mathrm{L}^{-1}\right)$ & 36.7 & 37.3 & 36.2 & 35.2 & 35.0 & 37.1 & 35.1 & 35.1 & 35.0 & - \\
\hline Reduction (\%) & $44.5^{\mathrm{a}}$ & $47.5^{\mathrm{a}}$ & $45.8^{\mathrm{a}}$ & $44.7^{\mathrm{a}}$ & $42.4^{\mathrm{ab}}$ & $45.0^{\mathrm{a}}$ & $35.4^{\mathrm{bc}}$ & $33.8^{\mathrm{c}}$ & $30.1^{\mathrm{c}}$ & 7.1 \\
\hline $\operatorname{VS}\left(\mathrm{g} \mathrm{L}^{-1}\right)$ & 28.6 & 32.3 & 31.2 & 29.0 & 30.3 & 30.9 & 30.1 & 30.8 & 30.7 & - \\
\hline Reduction (\%) & $50.3^{\mathrm{bc}}$ & $57.3^{\mathrm{a}}$ & $55.5^{\mathrm{abc}}$ & $52.1^{\mathrm{abc}}$ & $49.7^{\mathrm{c}}$ & $56.3^{\mathrm{ab}}$ & $37.7^{\mathrm{d}}$ & $35.9^{d}$ & $33.0^{\mathrm{d}}$ & 5.46 \\
\hline $\operatorname{Biogas}\left(\mathrm{L}_{\mathrm{N}}\right)$ & $14.6^{\mathrm{d}}$ & $17.9^{\mathrm{a}}$ & $15.6^{\mathrm{c}}$ & $14.5^{\mathrm{d}}$ & $5.4^{\mathrm{e}}$ & $16.7^{b}$ & $3.2^{\mathrm{f}}$ & $2.1^{\mathrm{g}}$ & $1.7^{\mathrm{g}}$ & 2.83 \\
\hline $\begin{array}{l}\text { Biogas } \\
\left(\mathrm{L}_{\mathrm{N}} \cdot \mathrm{kg}_{\text {TSadded }}{ }^{-1}\right)\end{array}$ & $221.6^{\mathrm{c}}$ & $266.7^{\mathrm{a}}$ & $241.2^{\mathrm{bc}}$ & $229.5^{\mathrm{bc}}$ & $86.2^{\mathrm{d}}$ & $251.2^{\mathrm{ab}}$ & $50.7^{\mathrm{e}}$ & $32.9^{\mathrm{e}}$ & $27.2^{\mathrm{e}}$ & 6.73 \\
\hline $\begin{array}{l}\text { Biogas } \\
\left(\mathrm{L}_{\mathrm{N}} \cdot \mathrm{kg}_{\mathrm{VSadded}}{ }^{-1}\right)\end{array}$ & $283.6^{\mathrm{ab}}$ & $308.4^{\mathrm{a}}$ & $280.5^{\mathrm{ab}}$ & $278.3^{\mathrm{b}}$ & $99.5^{\mathrm{c}}$ & $300.8^{\mathrm{ab}}$ & $59.2^{d}$ & $37.4^{d}$ & $31.0^{\mathrm{d}}$ & 6.57 \\
\hline
\end{tabular}

Control: SM without addition of carbon sources; SP 10/1: addition of SP in a C/N 10/1 setting; SP 13/1: addition of SP in a C/N 13/1 setting; SP 17/1: addition of SP in a C/N 17/1 setting; SP 22/1: SP addition in a C/N 22/1 setting; C 10/1: C addition in a C/N 10/1 setting; $C$ 13/1: $C$ addition in a $C / N$ 13/1 setting; $C$ 17/1: $C$ addition in a C/N 17/1 setting; $C$ 22/1: $C$ addition in a $C / N$ 22/1 setting. $C V$ : coefficient of variation.

${ }^{\mathrm{abc}}$ Line values with distinct superscripts differ by Tukey test $(\mathrm{P}<0.05)$.

especially in conditions where the participation of cassava was more representative, thus limiting the extent of the degradation of solids.

The interference of hydrocyanic acid was also observed by ADELEKAN \& BAMGBOYE (2009) in a study of the AcoD of different manures (poultry, swine, and cattle) with cassavapeels. The authors reported low production of biogas (35 L.kg $\left.{ }_{\text {TSadded }}{ }^{-1}\right)$ for the proportion of 1:1 (peels:SM) and concluded that, as the inclusion of peels to SM increased (2:1, 3:1, and 4:1), the production by $\mathrm{TS}_{\text {added }}$ decreased; they attributed this behavior to the lignocellulosic composition of the cassava peel and also to the presence of hydrocyanic acid, which makes the medium more acidic.

For the inclusion of the different carbon sources, the $10 / 1 \mathrm{C} / \mathrm{N}$ ratio provided the best result for the total biogas production. This $\mathrm{C} / \mathrm{N}$ ratio is lower than that recommended by GLANPRACHA $\&$ ANNACHHATRE (2016) and PANICHNUMSIN et al. (2010), which varies between 20-35, indicating that in studies with $\mathrm{AcoD}$, the $\mathrm{C} / \mathrm{N}$ ratio should not be adopted as the only parameter for decision making.

The largest total biogas production (Table 1) was reported for the SP 10/1 $\left(17.9 \mathrm{~L}_{\mathrm{N}}\right)$ treatment followed by $\mathrm{C} 10 / 1\left(16.7 \mathrm{~L}_{\mathrm{N}}\right)$, thereby demonstrating that these are the most beneficial combinations for the supply of semi-continuous biodigestors. For the specific productions of biogas by $\mathrm{TS}_{\text {added }}$, the treatments, control, SP 10/1, SP 13/1,
SP $17 / 1$, and C $10 / 1$, were the ones that presented higher yields (221.6, 266.7, 241.2, 229.5, and 251.2 $\mathrm{L}_{\mathrm{N}} \cdot \mathrm{kg}_{\mathrm{VSadded}}{ }^{-1}$ respectively), indicating that there were better degradations of the organic constituents in the substrate for these treatments, possibly because of a greater stabilization of the process and adaptation of anaerobic microorganisms.

According to the results obtained in this first stage with the batch biodigesters, SP $10 / 1$ and C $10 / 1$ treatments were selected to constitute the second stage of the experiment in biodigesters with a semicontinuous feed. As selection criteria, the best results for the total biogas production and biogas yield by $\mathrm{TS}_{\text {added }}$ were observed.

\section{Biodigesters with a semi-continuous feed}

The treatments in biodigesters with a semicontinuous feed did not differ in terms of TS and VS reductions (Table 2); however, the results obtained for these two parameters may not represent the real reductions, because sedimentation of substrates easily occurs when working with daily supply digesters without agitation of the biomass. As a consequence, there is effluent discharge with a minimized solids concentration, resulting in high substrate degradation in digestion, as already reported by COSTA et al. (2016). Therefore, it is believed that the reductions estimated for additions of SP or C (76.8\% and $75.7 \%$ for TS and $86.20 \%$ and $85.72 \%$ for VS, respectively) 
Table 2 - Characteristics of affluent and effluent, daily and specific biogas, and $\mathrm{CH}_{4}$ production in digesters with a semi-continuous feed in anaerobic co-digestion of swine manure (SM), sweet potato (SP), and cassava (C).

\begin{tabular}{|c|c|c|c|c|c|}
\hline \multirow[t]{2}{*}{ Parameters } & \multirow[t]{2}{*}{ Unit } & \multicolumn{3}{|c|}{ 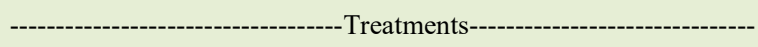 } & \multirow[t]{2}{*}{$\mathrm{CV}(\%)$} \\
\hline & & Control & SP $10 / 1$ & C $10 / 1$ & \\
\hline TS (afflu.) & $\mathrm{g} \mathrm{L}^{-1}$ & 17.0 & 16.2 & 16.3 & - \\
\hline Reduction & $\%$ & $76.8^{\mathrm{a}} \pm 1.1$ & $75.7^{\mathrm{a}} \pm 0.8$ & $76.0^{\mathrm{a}} \pm 0.6$ & 1.16 \\
\hline VS (afflu.) & $\mathrm{g} \mathrm{L}^{-1}$ & 13.8 & 13.5 & 13.6 & - \\
\hline Reduction & $\%$ & $86.2^{\mathrm{a}} \pm 0.8$ & $85.7^{\mathrm{a}} \pm 0.3$ & $85.7^{\mathrm{a}} \pm 0.2$ & 0.66 \\
\hline C (afflu.) & $\%$ & 28.70 & 38.56 & 38.13 & - \\
\hline Reduction & $\%$ & 22.72 & 45.51 & 42.41 & - \\
\hline N (afflu.) & $\%$ & 3.37 & 3.18 & 3.09 & - \\
\hline Reduction & $\%$ & 10.39 & 7.55 & 0.97 & - \\
\hline Biogas & $\mathrm{L}_{\mathrm{N}} \cdot \mathrm{d}^{-1}$ & $20.7^{\mathrm{c}} \pm 0.1$ & $24.3^{\mathrm{a}} \pm 0.1$ & $24.0^{\mathrm{b}} \pm 0.1$ & 0.29 \\
\hline Biogas & $\mathrm{L}_{\mathrm{N}} \cdot \mathrm{kg}_{\text {TSadded }}{ }^{-1} \cdot \mathrm{d}^{-1}$ & $607.8^{b} \pm 27.2$ & $752.0^{\mathrm{a}} \pm 15.7$ & $734.4^{\mathrm{a}} \pm 15.2$ & 2.84 \\
\hline Biogas & $\mathrm{L}_{\mathrm{N}} \cdot \mathrm{kg}_{\text {VSadded }}{ }^{-1} \cdot \mathrm{d}^{-1}$ & $752.5^{b} \pm 33.6$ & $901.5^{\mathrm{a}} \pm 18.7$ & $883.1^{\mathrm{a}} \pm 18.3$ & 2.85 \\
\hline $\mathrm{CH}_{4}$ & $\mathrm{~L}_{\mathrm{N}} \cdot \mathrm{kg}_{\text {VSadded }}{ }^{-1} \cdot \mathrm{d}^{-1}$ & $449.5^{\mathrm{c}} \pm 23.0$ & $590.5^{\mathrm{a}} \pm 23.9$ & $546.8^{b} \pm 14.9$ & 3.68 \\
\hline $\mathrm{CH}_{4}$ & $\%$ & $59.7^{\mathrm{c}} \pm 0.7$ & $65.5^{\mathrm{a}} \pm 1.4$ & $61.9^{b} \pm 1.1$ & 1.75 \\
\hline
\end{tabular}

Control: SM without addition of carbon sources (control treatment); SP 10/1: addition of SP in an adjustment of C/N 10/1; C 10/1: addition of $\mathrm{C}$ in an adjustment of $\mathrm{C} / \mathrm{N} \mathrm{10/1;CV}$ : coefficient of variation.

${ }^{a b c}$ Line values with distinct superscripts differ by Tukey test $(\mathrm{P}<0.05)$.

were overestimated and do not reflect the actual degradation of the substrates in AcoD.

The AcoD of SM and cassava pulp (a by-product of starch extraction) was studied by PANICHNUMSIN et al. (2010) in digesters with a semi-continuous feed under mesophilic conditions $\left(37^{\circ} \mathrm{C}\right)$ via 15 -day HRT and agitation for 15 minutes every half an hour. The reductions reported by the authors for the proportion of 20:60 (pulp:SM; C/N, $17 / 1)$ and for SM monodigestion $(\mathrm{C} / \mathrm{N}, 14 / 1)$ were similar, with these treatments averaging 39\% for TS and $47 \%$ for VS. The reduction in TS and VS reported by the authors is lower than that found in the present study, which is probably due to differences in the agitation system used in the biodigesters, which affects the value observed in the effluent for degradation of TS and VS.

The inclusion of SP and $\mathrm{C}$ in the AcoD substrates increased the production of biogas and $\mathrm{CH}_{4}$ when compared to the control (Table 2). The SP 10/1 treatment presented the highest biogas production $\left(24.3 \mathrm{~L}_{\mathrm{N}} \cdot \mathrm{d}^{-1}\right)$ followed by C $10 / 1\left(24.0 \mathrm{~L}_{\mathrm{N}} \cdot \mathrm{d}^{-1}\right)$. These values represented an increase of $17.5 \%$ and $15.8 \%$ in daily biogas production for SP 10/1 and C 10/1; respectively, when compared to the control treatment. During the whole monitoring process, the specific production of biogas and methane by $\mathrm{VS}_{\text {added }}$ was higher in the treatments with the inclusion of tuberous roots than in the control (Figure 1), showing the stability of the AcoD process.

The specific production values of biogas and $\mathrm{CH}_{4}$ by $\mathrm{TS}_{\text {added }}$ and $\mathrm{VS}_{\text {added }}$ from the SP 10/1 and C 10/1 treatments did not differ and were higher than in the control treatment (Table 2). Compared to the control, the specific biogas and $\mathrm{CH}_{4}$ productions by $\mathrm{VS}_{\text {added }}$ increased by $19.8 \%$ and $31.4 \%$ for SP $10 / 1$, and by $17.4 \%$ and $21.7 \%$ for $\mathrm{C} 10 / 1$, respectively. This increase observed in biogas and $\mathrm{CH}_{4}$ production indicated that the adjustment of the $\mathrm{C} / \mathrm{N}$ ratio in the medium under digestion, through the addition of roots, increased the availability of easily degradable carbohydrates to anaerobic microorganisms.

Working with semi-continuous digesters with a 30-day HRT and 4\% TS, ANDRADE et al. (2016) reported a biogas yield of $843 \mathrm{~L}_{1 \text { atm. } 25^{\circ} \mathrm{C}}$. $\mathrm{kg}_{\text {VSadded }}{ }^{-1}$ for the AcoD of SM with $10 \%$ (volume/ volume) cassava wastewater, which is also called "manipueira" (liquid residue from cassava starch extraction). The biogas yield reported by the authors was lower compared to the C 10/1 treatment $\left(883.1 \mathrm{~L}_{\mathrm{N}} \cdot \mathrm{kg}_{\mathrm{VSadded}^{-1}}{ }^{-1}\right)$ due to the composition of the "manipueira," which is less rich in carbohydrates; and therefore, resulted in lower biogas yield potential.

The specific production of $\mathrm{CH}_{4}$ of 217 L. $\mathrm{kg}_{\mathrm{VSadded}^{-1}}{ }^{-1}$ for $\mathrm{SM}$ in monodigestion, reported

Ciência Rural, v.50, n.10, 2020. 
by PANICHNUMSIN et al. (2010), is lower than the value reported in the present study of 449.5 $\mathrm{L}_{\mathrm{N}} \cdot \mathrm{kg}_{\mathrm{VSadded}}{ }^{-1}$. With the inclusion of cassava pulp, the authors obtained an increase in the specific production of $\mathrm{CH}_{4}$ up to a proportion of $60 \%$, from which the production decreased. For the 20:80 ratio (pulp:SM), the specific production of $\mathrm{CH}_{4}$ was 227 L. $\mathrm{kg}_{\mathrm{vSadded}}{ }^{-1}$, which is lower than that reported in the present study for the corresponding inclusion (20\%), and which occurred under the conditions of SP or C in the ratio of $10 / 1$ with 590.5 and $546.8 \mathrm{~L}_{\mathrm{N}} \cdot \mathrm{kg}_{\mathrm{VSadded}}{ }^{-1}$, respectively. These differences in methane production can be attributed to differences in the composition of the waste used and the different digestion conditions, such as the HRT, which was 15 days in the study performed by PANICHNUMSIN et al. (2010) and 30 days in the present study. Another justification for such differences may be the carbon source that was used, since PANICHNUMSIN et al. (2010) used cassava pulp, which has a higher concentration of fibers with difficult degradation and a lower concentration of starch than cassava in natura, which was used in this study.

The AcoD of cattle manure with residues (peels) of potato was evaluated by SANAEIMOGHADAM et al. (2014) in semi-continuous feeding biodigesters under mesophilic conditions (35$37^{\circ} \mathrm{C}$ ), an HRT of 50 days, $7 \% \mathrm{TS}$, and 10 minutes every half an hour of agitation. The concentration of $\mathrm{CH}_{4}$ in biogas reported by the authors was $58.8 \%$ in manure under monodigestion and $62.1 \%$ in an 80:20 treatment. In the present study, there was also an increase in the $\mathrm{CH}_{4}$ content of biogas when $\mathrm{SP}$ and $\mathrm{C}$ were added as carbon sources. The SP 10/1 treatment presented the highest concentration of $\mathrm{CH}_{4}(65.5 \%)$ in the biogas composition (Table 2), followed by the C $10 / 1$ treatment $(61.9 \%)$ and the control (59.7\%). Therefore, the AcoD of the SM with $\mathrm{SP}$ or $\mathrm{C}$, besides promoting an increase in the biogas production, provided a better quality of this biogas, increasing the $\mathrm{CH}_{4}$ concentration.

There was a decrease $(\mathrm{P}<0.05)$ in the alkalinity of the affluent and effluent for the AcoD treatments in comparison to the control treatment (Figure 2), with lower alkalinity in the affluent and effluent observed in the treatment C 10/1 (1479 and $2466 \mathrm{mg} \mathrm{CaCO}_{3} \mathrm{~L}^{-1}$, respectively). For the $\mathrm{AD}$ process to occur satisfactorily, the alkalinity should have values between 1000 and $5000 \mathrm{mg} \mathrm{CaCO}_{3} \mathrm{~L}^{-1}$, but, in order to keep the digestion process stable and well buffered, a concentration of 1500 to 3000 $\mathrm{mg} \mathrm{CaCO}_{3} \mathrm{~L}^{-1}$ is required (GERARDI, 2003). In this study, the mean alkalinity value for the effluent was $2571 \mathrm{mg} \mathrm{CaCO}_{3} \mathrm{~L}^{-1}$, which is within the optimal range. In the AcoD of cassava pulp and SM (pulp:SM), PANICHNUMSIN et al. (2010) reported values ranging from 1100 (80:20) to 4500 (20:80) mg $\mathrm{CaCO}_{3} \mathrm{~L}^{-1}$, considering the pulp a poor substrate in nutrient supply and buffering capacity.

In a study by ABOUDI et al. (2015), the authors observed beneficial effects on process stability and biodegradability in the AcoD of SM and beet cossettes (beet leftovers from sugar production), when the volatile acidity/alkalinity

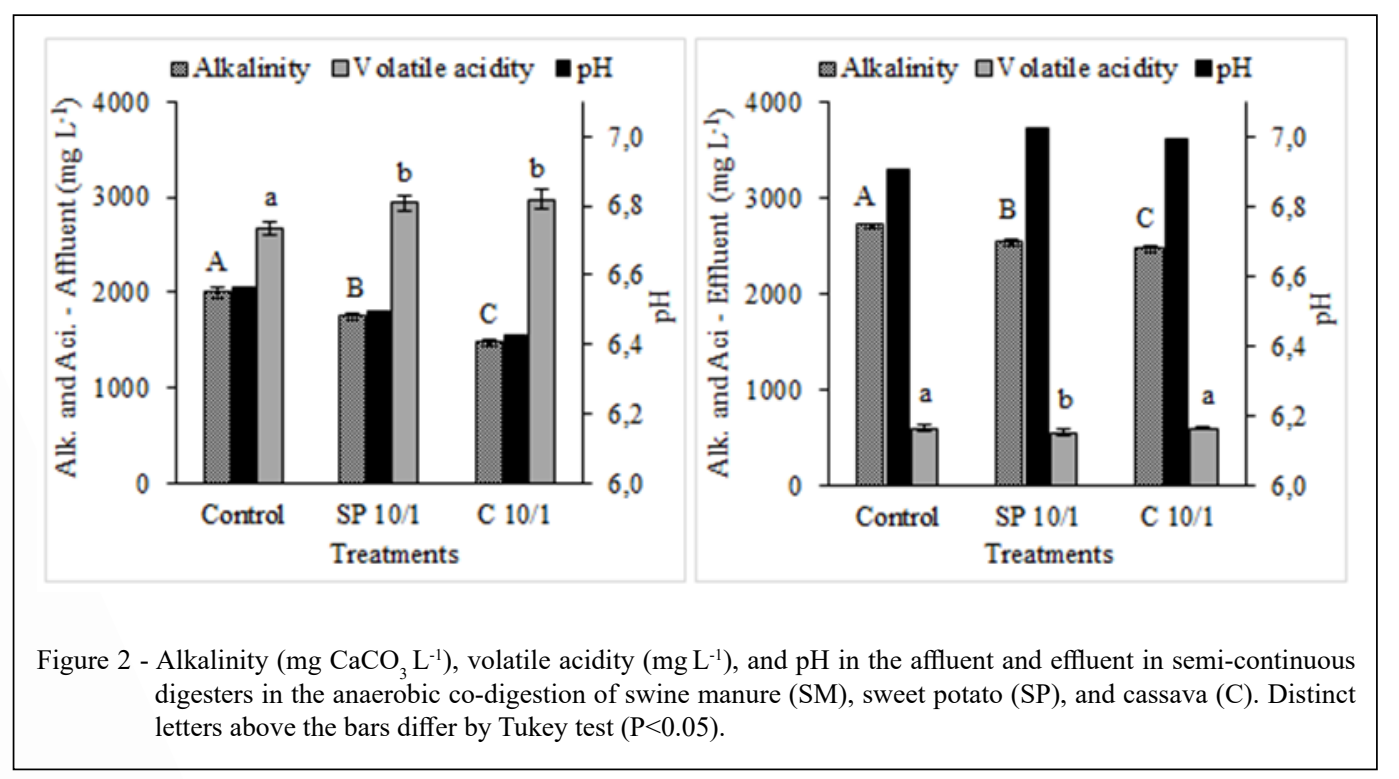

Ciência Rural, v.50, n.10, 2020. 
ratio had an upper limit of 0.4 , which is considered the maximum value for maintaining the stability of the AD. In the present study, a ratio of 0.2 (effluent) was reported for all treatments, and this stability may have been achieved by the buffer capacity of the SM that likely managed to keep the process within acceptable levels for the microorganisms. The carbon sources used and the quantity of them did not impair the buffering capacity of the SM.

The stability of the AD process was associated with a high HRT and low concentration of TS, which helped to keep the system from becoming overloaded. Thus, benefits were obtained from the inclusion of carbon sources, with a $\mathrm{C} / \mathrm{N}$ ratio below that recommended by the literature (20-35) (PANICHNUMSIN et al., 2010; GLANPRACHA \& ANNACHHATRE, 2016), suggesting that the $\mathrm{C} / \mathrm{N}$ ratio in a substrate in digestion cannot be the only parameter considered to estimate the effect of a substrate on the expected biogas yield.

\section{CONCLUSION}

The inclusion of sweet potato and cassava in the $10 / 1 \mathrm{C} / \mathrm{N}$ ratio in AcoD with swine manure increased the specific production of $\mathrm{CH}_{4}$ by $\mathrm{VS}_{\text {added }}$ by $31.5 \%$ and $21.8 \%$, respectively, in comparison to the isolated digestion of the manure, highlighting the benefits of AcoD in optimizing the production process of this fuel gas.

\section{ACKNOWLEDGEMENTS}

This study was carried out with financial support and a master's degree scholarship granted by the Coordination for the Improvement of Higher Education Personnel (Capes) and financial support by the Great Dourados Federal University.

\section{DECLARATION OF CONFLICT OF INTERESTS}

The authors declare no conflict of interest. The founding sponsors had no role in the design of the study; in the collection, analyses, or interpretation of data; in the writing of the manuscript, and in the decision to publish the results.

\section{AUTHORS' CONTRIBUTIONS}

All authors critically reviewed the manuscript and approved the final version.

\section{REFERENCES}

ABOUDI, K. et al. Improvement of exhausted sugar beet cossettes anaerobic digestion process by co-digestion with pig manure. Energy Fuels, v.29, n.2, p.754-762, 2015. Available from:
$<$ https://pubs.acs.org/doi/abs/10.1021/ef502502a $>$. Accessed: Aug. 23, 2019. doi: 10.1021/ef502502a.

ADELEKAN, B. A. \& BAMGBOYE, A. I. Comparison of biogas productivity of cassava peels mixed in selected ratios with major livestock waste types. African Journal of Agricultural Research, v.4, n.7, p.571577, 2009. Available from: <https://www.researchgate. net/publication/228495285_Comparison_of_biogas_ productivity_of_cassava_peels_mixed_in_selected_ratios_with major livestock waste types>. Accessed: Aug. 23, 2019

ANDRADE, W. R. et al. Biogas production from ruminant and monogastric animal manure co-digested with manipueira. Archivos de Zootecnia, v.65, n.251, 2016. Available from: <https://www. redalyc.org/pdf/495/49549092014.pdf>. Accessed: Aug. 23, 2019.

APHA. American Public Health Association. Standard methods for examination of water and wastewater. 21 th ed. Washington: American Water Works Association, 1.368p. 2005. Accessed: Aug. 23, 2019.

BROWN, D. \& LI, Y. Solid state anaerobic co-digestion of yard waste and food waste for biogas production. Bioresource technology, v.127, p.275-280, 2013. Available from: <https://www. sciencedirect.com/science/article/pii/S0960852412014319>. Accessed: Dec. 16, 2019. doi: 10.1016/j.biortech.2012.09.081.

COSTA, M. S. S. de M. et al. A highly concentrated diet increases biogas production and the agronomic value of young bull's manure. Waste Management, v.48, p.521527, 2016. Available from: <https://www.sciencedirect. com/science/article/pii/S0956053X15301471?via\%3Dihub>. Accessed: Jun. 19, 2020. doi: 10.1016/j.wasman.2015.09.038.

DAMACENO, F. M. et al. Anaerobic co-digestion of sludge cake from poultry slaughtering wastewater treatment and sweet potato: Energy and nutrient recovery. Renewable Energy, v.133, p.489499, 2019. Available from: <https://www.sciencedirect.com/ science/article/pii/S0960148118312540>. Accessed: Aug. 23, 2019. doi: 10.1016/j.renene.2018.10.070.

DILALLO, R. \& ALBERTSON, O. E. Volatile acids by direct titration. Journal Water Pollution Control Federation, Alexandria, v.33, n.4, p.356-365, abr. 1961. Accessed: Aug. 23, 2019. Available from: <https://www.jstor.org/stable/25034391>. Accessed: Aug. 23, 2019.

DORNACK, C. Biogas production from organic waste and biomass - fundamentals and current situation. Journal Vietnamese Environment, v.3, n.1, p.43-49, 2012. Available from: $<$ https:// journals.qucosa.de/jve/article/view/30>. Accessed: Aug. 23, 2019. doi: 10.13141/jve.vol3.no1.pp43-49.

FERREIRA, D. F. Sisvar: a Guide for its Bootstrap procedures in multiple comparisons. Ciência e Agrotecnologia, Lavras, v.38, n.2, p.109-112, mar./abr. 2014. Available from: <http://www.scielo. br/scielo.php?pid $=$ S1413-70542014000200001\&script $=$ sci_ arttext>. Accessed: Aug. 23, 2019. doi: 10.1590/S141370542014000200001 .

GERARDI, M. H. The microbiology of anaerobic digesters. John Wiley \&Sons, 2003. Available from: <https:// onlinelibrary.wiley.com/doi/book/10.1002/0471468967>. Accessed: Aug. 23, 2019. 
GLANPRACHA, N. \& ANNACHHATRE, A. P. Anaerobic co-digestion of cyanide containing cassava pulp with pig manure. Bioresource Technology, v.214, p.112-121, 2016. Available from: <https://www.sciencedirect.com/science/article/pii/ S0960852416305661>. Accessed: Aug. 23, 2019. doi: 10.1016/j. biortech.2016.04.079.

HASSAN, M. et al. Batch and semi-continuous anaerobic codigestion of goose manure with alkali solubilized wheat straw: a case of carbon to nitrogen ratio and organic loading rate regression optimization. Bioresource Technology, v.230, p.24-32, 2017. Available from: <https://www.sciencedirect.com/science/ article/pii/S0960852417300457>. Accessed: Aug. 23, 2019. doi: 10.1016/j.biortech.2017.01.025.

LE, C. \& STUCKEY, D. C. Impact of feed carbohydrates and nitrogen source on the production of soluble microbial products (SMPs) in anaerobic digestion. Water Research, v. 122, p.10-16, 2017. Available from: < https://www.sciencedirect.com/science/ article/abs/pii/S0043135417304256>. Accessed: Aug. 23, 2019. doi: 10.1016/j.watres.2017.05.061.

LINHARES, A. L. F. de A. et al. Determinação quantitativa do ácido cianídrico em mandioca. e-Scientia, v.11, n.2, p.1-7, 2018. Available from: <https://revistas.unibh.br/dcbas/article/ view/2411>. Accessed: jan. 13, 2020.

LORIMOR, J. et al. Manure characteristics. Section 1. Mid-West Plan Service MWPS-18, Iowa, USA, 2000. p.18. Available from: $<$ https://www.canr.msu.edu/uploads/files/ManureCharacteristicsMWPS-18_1.pdf>. Accessed: Aug. 23, 2019.

MATA-ALVAREZ, J. et al. A critical review on anaerobic codigestion achievements between 2010 and 2013. Renewable and Sustainable Energy Reviews, v.36, p.412-427, 2014. Available from: <https://www.sciencedirect.com/science/article/abs/pii/ S1364032114002664>. Accessed: Aug. 23, 2019. doi: 10.1016/j. rser.2014.04.039.

MOLINUEVO-SALCES, B. et al. Vegetable processing wastes addition to improve swine manure anaerobic digestion: evaluation in terms of methane yield and SEM characterization. Applied energy, v.91, n.1, p.36-42, Mar. 2012. Available from: <https://www.sciencedirect.com/science/article/abs/pii/ S0306261911005812>. Accessed: Aug. 23, 2019. doi: 10.1016/j. apenergy.2011.09.010.

MONTORO, S. B. et al. Anaerobic co-digestion of sweet potato and dairy cattle manure: A technical and economic evaluation for energy and biofertilizer production. Journal of cleaner production, v.226, p.1082-1091, 2019. Available from: <https:// www.sciencedirect.com/science/article/pii/S0959652619312272>. Accessed: Aug. 23, 2019. doi: 10.1016/j.jclepro.2019.04.148.

OKUDOH, V. et al. The potential of cassava biomass and applicable technologies for sustainable biogás production in South Africa: a review. Renewable and Sustainable Energy Reviews, v.39, p.1035-1052, 2014. Available from: <https://www.sciencedirect. com/science/article/abs/pii/S1364032114005942>. Accessed: Aug. 23, 2019. doi: 10.1016/j.rser.2014.07.142.

PANICHNUMSIN, P. et al. Production of methane by codigestion of cassava pulp with various concentrations of pig manure. Biomass and Bioenergy, v.34, n.8, p.1117-1124, ago. 2010. Available from: <https://www.sciencedirect.com/science/ article/pii/S0961953410000930>. Accessed: Aug. 23, 2019. doi: 10.1016/j.biombioe.2010.02.018.

REN, J. et al. Performance and microbial community dynamics in a two-phase anaerobic co-digestion system using cassava dregs and pig manure. Bioresource technology, v.155, p.342-351, 2014. Available from: <https://www.sciencedirect.com/science/ article/pii/S0960852413019603>. Accessed: May, 06, 2020. doi: 10.1016/j.biortech.2013.12.120.

SANAEI-MOGHADAM, A. et al. Enhancement of biogas production by co-digestion of potato pulp with cow manure in a CSTR system. Applied biochemistry and biotechnology, v.173, n.7, p.1858-1869, 2014. Available from: <https://link.springer. com/article/10.1007/s12010-014-0972-5>. Accessed: Aug. 23, 2019. doi: 10.1007/s12010-014-0972-5.

SCHWINGEL, A. W. et al. Laying hen manure in anaerobic CoDigestion with glycerin containing different glycerol and impurity levels. Journal of Cleaner Production, v.215, p.1437-1444, 2019. Available from: <https://www.sciencedirect.com/science/ article/pii/S0959652619301428>. Accessed: Sep. 12, 2019. doi: 10.1016/j.jclepro.2019.01.125.

SIDDIQUE, M. N. I. \& WAHID, Z. A. Achievements and perspectives of anaerobic co-digestion: Areview. Journal of cleaner production, v.194, p.359-371, 2018. Available from: <https://www. sciencedirect.com/science/article/pii/S0959652618314951>. Accessed: Aug. 23, 2019. doi: 10.1016/j.jclepro.2018.05.155.

TABORDA, L. W. et al. Evaluation of the technical and economic feasibility of ethanol production in a pilot plant using sweet potatoes. Custos e @gronegócio, v.11, n.1, p.245-262, 2015. Available from: <http://www.custoseagronegocioonline. com.br/numero1v11/OK_14_etanol_english.pdf $>$. Accessed: Aug. 23, 2019.

THUMÉ, M. A. et al. Níveis críticos foliares de nutrientes de três cultivares de batata-doce, selecionados para a produção de etanol. Rev. Ceres, Viçosa, v.60, n.6, p.863-875, Dec. 2013. Available from: $<$ http://www.scielo.br/scielo.php?script=sci_arttext\&pid=S0034737X2013000600015\&lng=en\&nrm=iso>. Accessed: Aug. 23, 2019. doi: 10.1590/S0034-737X2013000600015.

TRAUTMANN, N. M. \& KRASNY, M. E. Composting in the classroom: Scientific inquiry for high school students. Cornell: Cornell University, 1997. 126p. Available from: $<$ https://ecommons. cornell.edu/bitstream/handle/1813/3338/?sequence $=1>$. Accessed: Aug. 23, 2019. 